\title{
Examine Leadership Qualities: Jack Welch Model is a Reference
}

\author{
K.Prabhakar Rajkumar, R. Padmapriya
}

\begin{abstract}
Management is actually quite essential in every organization. When there is a good management after that the functionality of the employees will definitely additionally be excellent. The major objectives of the research study are to explore the leadership type that adds to staff member efficiency. Primary records have been picked up via problem the survey. A total amount of 175 respondents are taken as example for the study. The research takes advantage of statistical procedures including Percent analysis, Chi-square test, ANOVA in evaluating the records. The research reveals that remarkable should possess really good communication along with their worker community which are going to make excellent team and the premium must enjoy the project of the juniors always.
\end{abstract}

Keywords: Leadership, employee, performance and superior

\section{INTRODUCTION}

Leadership possesses in fact consistently maintained a challenging tourist attraction for male as well as additionally has in fact been really a hard-to-find subject for professionals. Management literature is all around along with prescribeds on simply exactly how to become an excellent forerunner. Supplying others for the purpose of doing a typical duty is actually crucial and also helpful provided that our company should handle duties which one man can easily certainly not conduct without the aid of others. Thereby, leadership has really been actually realized to a significantly better level being actually one ofthe considerable component of human duty. Due to the interest rate taken through nonprofessionals as well as likewise social as well as behavior professionals, the superiors which separate the one whom others obey from those who follow him, as furthermore their communication process styles, have really commonly been in fact the object of wild guess as well as professional examination.

The significant significance of management is actually to secure job done due to the folks through sending each one of all of them in the very best view. It signifies staffs must be actually led therefore worrying be steered towards the usual intendeds. Leadership is in fact the excellent quality of the behaviour of people whereby they assist individuals or even their tasks in set up method. Actually, the companies contend even more via their leadership styles than by means of their products. Forerunners offer the provider the way of life which makes the products and development that he industries.

\section{SUGGESTING OF LEADERSHIP}

Revised Manuscript Received on November 05, 2019.

Dr.K.PRABHAKAR RAJKUMAR, Associate Professor, Department of Commerce, Periyar University, Salem, Tamil Nadu, India

R. PADMAPRIYA, Ph.D Research Scholar, Department of Commerce, Periyar University, Salem, Tamil Nadu, India. Email kudalkprk6@yahoo.co.in.
Depending on to Davis, "Leadership is the capacity to encourage others to discover determined objectives easily. It is actually the private element which links a staff with each other as well as likewise motivates them in the direction of their goals"

According to Knootz and also O'Donell, "Leadership is in fact the capacity of a supervisor to trigger workers to handle confidence and likewise passion."

Depending On to Peter Drucker, "Leadership is in fact the hauling of man's vision to higher attractions, the raising of a male's functionality to a much higher criteria, the structure of a fella's character past its personal regular limits"

Depending upon to George R. Terry," The are going to absolutely to carry out is really triggered with leadership and also warm desire for results is become shedding interest for successful achievement by professional use leadership".

\section{JACK WELCH CONCEPT}

Port Welch attended to leadership and company what Panthera pardus Forest is actually developing for golf-increased seat and also specified an all new specification in efficiency; a requirements that the stock exchange determined as well as additionally rewarded as GE allocations, throughout his time period, had a "Welch Expense" together with GE parts trading at 40-- fifty times earnings, about double the average for a major USA supplier.

Via his time at GE, operating some of the planet's largest organizations, Port Welch realized the qualities of an excellent leader; these features wound up being actually known as the 4E's of GE leadership.

\section{ENERGY}

Individuals alongside energy affection to go, go, go. A lot of us identify folks such as this. These are individuals who have infinite energy that rise every morning simply irritating to attack the project available; individuals that transfer at 95 miles an hour in a 55 mile-an-hour globe.

\section{ENERGIZES}

Know exactly how to trigger others to conduct, they detail sight and additionally influence individuals to act on that eyesight. They understand exactly just how to get individuals thrilled concerning a cause or campaign. 


\section{Jack Welch 4E's of Leadership}

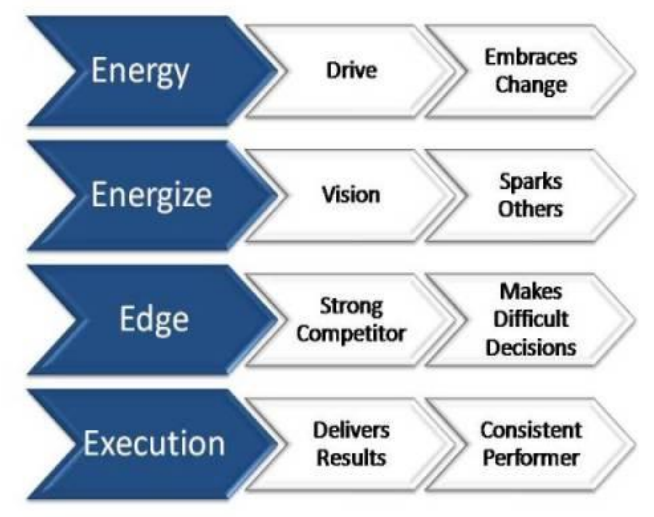

\section{EDGE}

Those along with upper hand are actually very competitive styles. They recognize just how to generate the tough, immediate selections. Peter Drucker refers to as the "urgent" options: opting for, advertising, and also firing.

The most suitable innovators that how to enhance energy in addition to side right in to action as well as results. They know precisely how to accomplish.

\section{STATEMENT OF THE PROBLEM}

Leadership work today are actually requiring especially due to the fact that our company stay in an experience economic weather as well as function throughout proficiency workers. Leadership effectiveness within this specific circumstance will definitely depend on precisely how the innovator propels his individuals to acquire incredible outcomes. While other resources like gadget, product, etc. Having a pleased manpower is actually very much essential for gentle working of every association.

Because of this research study is done to identify whether the laborers are delighted along with the leadership excellent quality, interaction, decision making, establishing objective, instruction, inspiration of the agency. There is in fact furthermore an immediate need to focus on the person of innovators to ensure that their skill-sets as well as also capacities are durable enough to equivalent present-day opportunities. Reliable leaders can simply count on problems and rapidly respond to brand-new facts. Industrial planet today uses bunches of remarkable as well as however, hard chances for development. Forerunners are in fact as a result called to re-think normal ways along with participate in a greater as well as additionally ingenious obligation to encounter all of all of them in addition to idea as well as digestive tracts.

\section{OBJECTIVES OF THE STUDY}

To look into the leadership creates that brings about worker performance.

To disclose the relationship between the reputable leadership types and additionally efficiency of workers.
To comprehend the usefulness of leadership concepts in the team member functions.

To build the style that reveals connection amongst unique kinds of leadership and also employee functions.

\section{RESEARCH PROCEDURE}

This tactic describes involving the total target of analysis type, info assortment method, testing procedure, construction of collection of questions, resources of evaluation.

\section{EXAMINATION IDEA}

A research study format is really the program of health and wellness disorder for collection and also assessment of records in manner in which strives to mixture importance to the analysis study reason alongside economic situation in treatment. The analysis study is actually descriptive in attribute. As it is actually clarifying, the performance of leadership kinds amongst employees.

\section{TESTING TECHNIQUE}

The research study relies on significant files. An aviator research study is in fact provided with 30 participants to sanction the set of questions in addition to confirm the workability of the study. Based on the fly analysis study, the questionnaire is fine-tuned correctly to create reaction coming from the example team. To research the Beneficial Tasting Method is adopted.

\section{SAMPLING MEASUREMENTS}

An overall amount of 175 workers are in fact taken as instance for this research study. On the random method, polls were actually distributed to get the called for details for this research.

\section{PROCEDURE OF RELEVANT INFORMATION VARIETY}

The reports for this research study are actually of pair of kinds: -

Primary information

Indirect records

\section{LOGICAL TOOLS}

The observing analytical resources are utilized in the research Percent Analysis

Chi-- straight examination

ANOVA.

Connection Examination.

\section{RESTRICTIONS OF THE RESEARCH STUDY.}

175 respondent's samples may certainly not be actually generalised to the entire cosmos.

As the subject matter for the investigation is actually huge in attributes of all the concerns relating to the study can perhaps not assessed and also born in mind.

The information gathered is actually Coimbatore Area alone as well as is may simply certainly not be generalized for all places. 


\section{REVIEW OF LITERARY WORKS}

Liaqat Ali (2019), "Effect of Leadership Types on Company Performance - A Research Study of Community Market College, Bacha Khan University Charsadda". This study has actually been executed along with objective to look into the impact of leadership types (Laissez-faire leadership, Transactional leadership in addition to Transformational leadership) on business performance as a case history of social industry college (Bacha Khan College Charsadda, Pakistan). The investigation study took advantage of primary reports which was picked up by means of surveys as research study musical instrument. An example measurements of 110 participants. Detailed stats, frequency table, dependability assessment, partnership and additionally regression analysis have actually been actually made use of to review the reports. They locate that a system improvement in Laissez-faire leadership type, a system increase in Flexible leadership style as well as likewise a device surge in Transformational leadership type are going to certainly cause improve in organization's performance.

Alemu Muleta Kebede and also Getnet Worku Demeke (2017 ), "The Impact of Leadership Designs on Employee Job Fulfillment in Ethiopian Community Colleges". This research study checks out the impact of leadership styles on team member' job fulfillment in social universities in Ethiopia. Key files was actually collected using questionnaire method making use of questionnaire along with the employees of the company. The example size is actually 8603 full-time employees as well as also staffs in those 4 universities. Binary logistic regression examinations have actually been in fact utilized to assess the information. The outcomes made known that teachers choose a trendsetter that shows a transformational style/behavior. It stands up to main reason that transformational forerunners enhance the liberty of academic team.

Abdulkadir Mohamud Dahie, Ali Abdi Mohamed (Aligees) as well as also Raqia Ahmed Mohamed (2017), "Leadership Style and Business Devotion: Study originating from University of Somalia". Goals to have a look at the impact of negotiable leadership on company dedication. Survey was actually used to acquire records arising from example of 95 respondents via using easy screening technique. Hookup assessment and also Regression evaluation have in fact been actually utilized to analyze the records. They find that Administrations ought to provide prosperous leadership layout for speakers that are mosting likely to strengthen functionality as well as likewise firm commitment.

Ilona Buciuniene and also Vida Skudiene (2008), "Effect of Leadership Types on Laborers' Company Dedication in Lithuanian Production Business". The objective of this particular specific research study is to look into the hookup between leadership types as well as also personnel provider devotion. Primary files have in fact been actually built up with issue the collection of inquiries. The full populace of 224 center level administrators from five manufacturing companies in Lithuania. Standard deviation as well as Spearman's connection coefficient have been used to determine the documents. Maybe advised that a transformational leadership style has really good associations with laborer's commitment in psychological, market value, feelings and also financial key phrases.

\section{ANAL YSIS OF DATA}

\section{I) Percentage Analysis}

Table No: 1 : Demographic Profile

\begin{tabular}{|c|c|c|c|}
\hline S.Na & Determinants & No of Respondents ( $N=175$ ) & Percentage (\%) \\
\hline 1 & $\begin{array}{l}\text { Designation } \\
\text { Production Department } \\
\text { Quality Control Department } \\
\text { Dispatch Department } \\
\end{array}$ & $\begin{array}{l}70 \\
50 \\
55 \\
\end{array}$ & $\begin{array}{l}40.0 \\
28.6 \\
31.4 \\
\end{array}$ \\
\hline 2 & $\begin{array}{l}\text { Gender } \\
\text { Male } \\
\text { Female } \\
\end{array}$ & $\begin{array}{l}135 \\
40 \\
\end{array}$ & $\begin{array}{l}77.1 \\
22.9 \\
\end{array}$ \\
\hline 3 & $\begin{array}{l}\text { Age } \\
\text { Less than } 20 \text { years } \\
20 \text { to } 35 \text { years } \\
36 \text { to } 50 \text { years } \\
\text { Above } 50 \text { years }\end{array}$ & $\begin{array}{c}18 \\
120 \\
33 \\
4 \\
\end{array}$ & $\begin{array}{l}10.3 \\
68.6 \\
18.9 \\
2.3 \\
\end{array}$ \\
\hline 4 & $\begin{array}{l}\text { Experience } \\
\text { Below } 5 \text { years } \\
5 \text { to } 10 \text { years } \\
11 \text { to } 15 \text { years } \\
\text { Above } 15 \text { years }\end{array}$ & $\begin{array}{l}67 \\
73 \\
25 \\
10 \\
\end{array}$ & $\begin{array}{l}38.3 \\
41.7 \\
14.3 \\
5.7 \\
\end{array}$ \\
\hline 5 & $\begin{array}{l}\text { Educational Qualification } \\
\text { No formal education } \\
\text { High School } \\
\text { Graduate } \\
\text { Professional }\end{array}$ & $\begin{array}{c}19 \\
69 \\
83 \\
4 \\
\end{array}$ & $\begin{array}{l}10.9 \\
39.4 \\
47.4 \\
2.3\end{array}$ \\
\hline 6 & $\begin{array}{l}\text { Place of Residence } \\
\text { Urban } \\
\text { Semi- wrban } \\
\text { Rural }\end{array}$ & $\begin{array}{l}17 \\
127 \\
31\end{array}$ & $\begin{array}{l}9.7 \\
72.6 \\
17.7\end{array}$ \\
\hline 7 & $\begin{array}{l}\text { Monthly income } \\
\text { Below Rs. } 10,000 \\
\text { Rs. } 10,001 \text { - Rs. } 15,000 \\
\text { Rs. } 15,001 \text { - Rs. } 25,000 \\
\end{array}$ & $\begin{array}{l}90 \\
58 \\
27 \\
\end{array}$ & $\begin{array}{l}51.4 \\
33.1 \\
15.4\end{array}$ \\
\hline 8 & $\begin{array}{l}\text { Type of Leader } \\
\text { Autocratic } \\
\text { Democratic } \\
\text { Consultative } \\
\end{array}$ & $\begin{array}{l}25 \\
79 \\
71\end{array}$ & $\begin{array}{l}14.3 \\
45.1 \\
40.6\end{array}$ \\
\hline 9 & $\begin{array}{c}\text { Kind of Leadership } \\
\text { Autocratic } \\
\text { Democratic } \\
\text { Consultative } \\
\end{array}$ & $\begin{array}{l}33 \\
70 \\
72\end{array}$ & $\begin{array}{l}18.9 \\
40.0 \\
41.1 \\
\end{array}$ \\
\hline
\end{tabular}

\begin{tabular}{|c|c|c|c|}
\hline 10 & $\begin{array}{l}\text { Kind of Qualities } \\
\text { Motivating } \\
\text { Decision making } \\
\text { Communicating } \\
\end{array}$ & $\begin{array}{l}24 \\
69 \\
82 \\
\end{array}$ & $\begin{array}{l}13.7 \\
39.4 \\
46.9 \\
\end{array}$ \\
\hline 11 & $\begin{array}{l}\text { Feel about relationship between leaders } \\
\text { Cordial } \\
\text { Formal } \\
\text { Workable }\end{array}$ & $\begin{array}{l}12 \\
84 \\
79\end{array}$ & $\begin{array}{r}6.9 \\
48.0 \\
45.1\end{array}$ \\
\hline 12 & $\begin{array}{l}\text { Leader respond to our complaints } \\
\text { Yes } \\
\text { No }\end{array}$ & $\begin{array}{l}133 \\
42 \\
\end{array}$ & $\begin{array}{l}76.0 \\
24.0\end{array}$ \\
\hline 13 & $\begin{array}{l}\text { Superior appreciate to our work } \\
\text { Yes } \\
\text { No }\end{array}$ & $\begin{array}{l}122 \\
53 \\
\end{array}$ & $\begin{array}{l}69.7 \\
30.3 \\
\end{array}$ \\
\hline & Total & 175 & 100.0 \\
\hline
\end{tabular}

The investigation study possesses actually positioned that many $70(40.0 \%)$ of the individuals are in fact doing work in production division. A large number $135(77.1 \%)$ of the respondents are really male. A large number 120 (68.6\%) participants are actually stemming from the age between 20-35 years. Large number 73 (41.7\%) attendees had between 5-10 years of understanding in this company and large number $83(47.4 \%)$ attendees are graduate owners. Large number $127(72.6 \%)$ of the respondents are staying in semi-modern location. Numerous 90 (51.4\%) of the individuals normal month-to-month income is actually under Rs.10,000 A large number $79(45.1 \%)$ of the attendees managers are self-governing signs. 
Many 72 (41.1\%) individuals feel like consultatory leadership and after that the majority $82(46.9 \%)$ individuals possessed like to corresponding procedure of a forerunner. Majority 84 (48.0\%) respondents had really felt about expert link along with an innovator. A a great deal $133(76.0 \%)$ of the attendees have mentioned leader react to our grievances as well as likewise most $122(69.7 \%)$ of the participants had feeling premium appreciate to our project.

\section{II) CHI - SQUARE TEST}

TABLE NO: 2

\section{DEMOGRAPHIC PROFILE AND LEADERSHIP STYLES}

H0: There is no considerable partnership between the two types that are actually demographic account of the workers as well as their leadership types

H1: There is actually substantial relationship in between demographic account of the staff members and their leadership types.

Having said that, as the worked out $\chi^{\wedge} 2$ worth is above the dining table at 5 per cent level, the ineffective hypothesis is rejected. For that reason, it is actually ended that there is a considerable association in between classification, gender, grow older, experience, academic certification, address, month to month revenue, type of leader, feel concerning relationship between innovator and also forerunner react to our grievances of the workers and their leadership types.

\begin{tabular}{|c|l|c|c|c|c|}
\hline \multicolumn{2}{|c|}{ Variables } & D.f $\mathrm{N}_{0}$ & $\begin{array}{c}\text { Calculated } \\
\chi^{2} \text { Value }\end{array}$ & $\begin{array}{c}\text { Table } \\
\text { value }\end{array}$ & Result \\
\hline 1 & Designation & 4 & 18.868 & 9.488 & Significant \\
\hline 2 & Gender & 2 & 7.141 & 5.991 & Significant \\
\hline 3 & Age & 6 & 21.501 & 12.592 & Significant \\
\hline 4 & Experience & 6 & 26.641 & 12.592 & Significant \\
\hline 5 & Educational Qualification & 6 & 28.070 & 12.592 & Significant \\
\hline 6 & Place of Residence & 4 & 9.700 & 9.488 & Significant \\
\hline 7 & Monthly income & 4 & 15.318 & 9.488 & Significant \\
\hline 8 & Type of Leader & 4 & 37.277 & 9.488 & Significant \\
\hline 9 & Kind of Leadership & 4 & 8.994 & 9.488 & Not Significant \\
\hline 10 & Kind of Qualities & 4 & 5.802 & 9.488 & Not Significant \\
\hline 11 & Feel about relationship between leader & 4 & 10.523 & 9.488 & Significant \\
\hline 12 & Leader respond to our complaints & 2 & 7.764 & 5.991 & Significant \\
\hline 13 & Superior appreciate to our work & 2 & 5.350 & 5.991 & Not Significant \\
\hline
\end{tabular}

\section{III) ANOVA}

Table No: 3

Anova Table Showing The Difference In Mean Scores Between Leadership Styles \& Demographic Profile

$\mathrm{H} 0$ : There is no considerable connection between both types that are group profile page of the staff members as well as their leadership styles

H1: There is considerable relationship between demographic profile page of the staff members and their leadership types.

\begin{tabular}{|c|c|c|c|c|c|c|}
\hline \multicolumn{2}{|c|}{ ANOVA } & $\begin{array}{l}\text { Sum of } \\
\text { Squares }\end{array}$ & df & $\begin{array}{l}\text { Dleanl } \\
\text { Square }\end{array}$ & F & Sig, \\
\hline \multirow{3}{*}{ Designation } & Betwreen Groups & 4.218 & 2 & 2.109 & 3.036 & 0.051 \\
\hline & Within Groups & 119.496 & 172 & 0.695 & & \\
\hline & Total & 123.714 & 174 & & & \\
\hline \multirow{3}{*}{ Gender } & Between Groups & 1.259 & 2 & 0.630 & 3.658 & 0.028 \\
\hline & Within Groups & 29.598 & 172 & 0.172 & & \\
\hline & Total & 30.857 & 174 & & & \\
\hline \multirow{3}{*}{ Age } & Betwreen Groups & 2.767 & 2 & 1.384 & 3.888 & 0.022 \\
\hline & Within Groups & 61.210 & 172 & 0.336 & & \\
\hline & Total & 63.977 & 174 & & & \\
\hline \multirow{3}{*}{ Experience } & Between Groups & 1.105 & 2 & 0.533 & 0.742 & 0.478 \\
\hline & Within Groups & 128.129 & 172 & 0.745 & & \\
\hline & Total & 129.234 & 174 & & & \\
\hline \multirow{3}{*}{ Educational Qualification } & Betwieen Groups & 8.362 & 2 & 4.181 & 9.162 & 0.000 \\
\hline & Within Groups & 78.495 & 172 & 0.456 & & \\
\hline & Total & 86.857 & 174 & & & \\
\hline \multirow{3}{*}{ Place of Residence } & Between Groups & 2.062 & 2 & 1.031 & 3.956 & 0.021 \\
\hline & Within Groups & 44.818 & 172 & 0.261 & & \\
\hline & Total & 46.880 & 174 & & & \\
\hline \multirow{3}{*}{ Morthly income } & Betwreen Groups & 4.052 & 2 & 2.026 & 3.860 & 0.023 \\
\hline & Within Groups & 90.268 & 172 & 0.525 & & \\
\hline & Total & 94,320 & 174 & & & \\
\hline \multirow{3}{*}{ Type of Leader } & Betriven Groups & 16.789 & 2 & 8.395 & 21.512 & 0.000 \\
\hline & Within Groups & 67.119 & 172 & 0.390 & & \\
\hline & Total & 83.909 & 174 & & & \\
\hline
\end{tabular}

\begin{tabular}{|c|l|c|c|c|c|c|}
\hline \multirow{4}{*}{ Kind of Leadership } & Between Groups & 4.516 & 2 & 2.258 & 4.231 & 0.016 \\
\cline { 2 - 8 } & Within Groups & 91.793 & 172 & 0.534 & & \\
\hline & Total & 96.309 & 174 & & & \\
\hline \multirow{4}{*}{ Kind of Qualities } & Between Groups & .635 & 2 & 0.318 & 0.634 & 0.532 \\
\cline { 2 - 8 } & Within Groups & 86.142 & 172 & 0.501 & & \\
\cline { 2 - 8 } & Total & 86.777 & 174 & & & \\
\hline \multirow{3}{*}{$\begin{array}{c}\text { Feel about relationship } \\
\text { between leader }\end{array}$} & Between Groups & 3.723 & 2 & 1.861 & 5.195 & 0.006 \\
\hline & Within Groups & 61.626 & 172 & 0.358 & & \\
\cline { 2 - 8 } & Total & 65.349 & 174 & & & \\
\hline \multirow{2}{*}{$\begin{array}{c}\text { Leader respond to our } \\
\text { complaints }\end{array}$} & Between Groups & 1.416 & 2 & 0.708 & 3.993 & 0.020 \\
\hline & Within Groups & 30.504 & 172 & 0.177 & & \\
\cline { 2 - 8 } & Total & 31.920 & 174 & & & \\
\hline \multirow{2}{*}{$\begin{array}{c}\text { Superior appreciate to } \\
\text { our work }\end{array}$} & Between Groups & 1.130 & 2 & 0.565 & 2.712 & 0.069 \\
\cline { 2 - 8 } & Within Groups & 35.819 & 172 & 0.208 & & \\
\cline { 2 - 8 } & \multicolumn{1}{|c|}{ Total } & 36.949 & 174 & & & \\
\hline
\end{tabular}

The above table uncovers that the $\mathrm{p}$ value is lower than 0.05 . Consequently, zero opinion is actually declined. Therefore, there is a notable distinction in the mean credit scores ratings of the participants based upon leadership layouts relative to designation, sex, grow older, academic credentials, home, frequent month to month earnings, type of sign, sort of leadership, really feel pertaining to connection in between pioneer, forerunner react to our problems and likewise their superior cherish to our work. It is actually presumed that designation, sex, grow older, scholastic references, place of residence, month-to-month earnings, form of innovator, sort of leadership, experience pertaining to partnership in between forerunner, forerunner respond to our problems as well as their superior treasure to our job find out the leadership kinds.

IV) CORRELATION ANALYSIS

TABLE NO: 4

CORRELATION RELATIONSHIP BETWEEN LEADERSHIP STYLES

(ENERGY, ENERGIZE, EDGE AND EXECUTION) 


\begin{tabular}{|c|c|c|c|c|c|}
\hline \multicolumn{2}{|c|}{ Correlations } & Energy & Energize & Edge & Erecution \\
\hline \multirow{3}{*}{ Energy } & Pearson Correlation & 1 & $.669^{\circ *}$ & $.715^{\circ *}$ & $.456^{\circ}$ \\
\hline & Sig. (2-tailed) & & .000 & .000 & .000 \\
\hline & $\mathrm{N}$ & 175 & 175 & 175 & 175 \\
\hline \multirow{3}{*}{ Energize } & Pearson Correlation & $.669^{\circ *}$ & 1 & $603^{3 *}$ & $.483^{* *}$ \\
\hline & $\operatorname{Sig} .(2-$ tailed $)$ & .000 & & .000 & .000 \\
\hline & $\mathrm{N}$ & 175 & 175 & 175 & 175 \\
\hline \multirow{3}{*}{ Edge } & Pearson Correlation & $.715^{\circ *}$ & $603^{* 4}$ & 1 & $.738^{* *}$ \\
\hline & Sig. (2-tailed) & .000 & .000 & & .000 \\
\hline & $\mathrm{N}$ & 175 & 175 & 175 & 175 \\
\hline \multirow{3}{*}{ Erecution } & Pearson Correation & $.456^{\circ}$ & $.483^{\circ *}$ & $.738^{\circ 4}$ & 1 \\
\hline & Sig. (2-tailed) & .000 & .000 & .000 & \\
\hline & $\mathrm{N}$ & 175 & 175 & 175 & 175 \\
\hline
\end{tabular}

*. Correlation is significant at the 0.01 level (2-tailed).

Originating from the above dining table is actually Connection connection between Leadership Styles (Energy, Energize, Edge and also Implementation). These volumes assess the strength and also road of the straight link in between the 4 variables. The correlation coefficient might vary stemming from -1 to +1 , along with -1 proposing an outstanding unfavorable link, +1 recommending a perfect confident connection, as well as also 0 indicating no correlation in any way.

$>$ The Coefficient of Connection offers that there is in fact a notable exists between Energy as well as Energize.

$>$ The Coefficient of Connection offers that there is actually a considerable exists in between Energy and likewise Side.

$>$ The Coefficient of Partnership shows that there is actually a substantial exists in between Energy and also Implementation.

$>$ The Coefficient of Correlation shows that there is a significant exists between Energize and Energy.

$>$ The Coefficient of Relationship offers that there is a substantial exists between Energize and also Side.

$>$ The Coefficient of Connection provides that there is actually a notable exists in between Energize as well as Conclusion.

> The Coefficient of Hookup discloses that there is really a substantial exists between Edge and also Energy.

$>$ The Coefficient of Relationship provides that there is really a notable exists in between Side and also Energize.

$>$ The Coefficient of Connection shows that there is actually a considerable exists between Side in addition to Execution.

$>$ The Coefficient of Partnership discloses that there is a significant exists in between Execution and additionally Energy.

$>$ The Coefficient of Connection shows that there is a sizable exists in between Implementation as well as additionally Invigorate.

$>$ The Coefficient of Correlation discloses that there is a notable exists in between Completion in addition to Side.
The grievance panel might be comprised to handle the grievance promptly.

Improving employees participation in surveillance by means of obtaining recommendation coming from the staff members.

Enhance each financial \& non economic motivations to influence the staff members.

Top-notch should appreciate the task of the juniors continuously.

Top-notch needs to possess wonderful communication with their team member location which will establish great team. The affiliation must carry out the new advancements in addition to work improvement course.

\section{CONCLUSION}

Leadership participates in a crucial job fit the behavior as well as point of views of the individuals of an organization. It additionally calculates specifically how people would certainly socialize with one another so as to resolve problems in addition to take selections. The field of leadership undoubtedly not merely concentrates on interpersonal associations yet additionally values the duty of an inventor as a motivation and also energizer. The function of the review was actually to improve the understanding of occurring leadership inputs decided on affiliation in a developing financial condition.

Leadership is significantly significant in every association. When there is actually a terrific leadership after that the performance of the workers will surely additionally be superb. Via these group problems are taken care of, disagreements are really steered clear from, staff members receives superb assistance from the top-notches in managing the issues together with in group design. This motivates the staff members in the company to contribute even more and additionally think the environment in a taken it easy manner.

\section{REFERENCES}

1. Liaqat Ali (2019), "Impact of Leadership Types on Company Functionality - An Instance of Individuals Field College, Bacha Khan University Charsadda", Log of Multidisciplinary Approaches in Scientific Analysis, Quantity 4, Problem 1, pp. 26-40.

2. Alemu Muleta Kebede as well as Getnet Worku Demeke (2017), "The Influence of Leadership Styles on Employees Function Complete Satisfaction in Ethiopian Neighborhood Universities", Contemporary Command Investigation, Vol. Thirteen, No. 3, pp. 165-176.

3. Abdulkadir Mohamud Dahie, Ali Abdi Mohamed (Aligees) and likewise Raqia Ahmed Mohamed (2017), International Publication of Concept Scientific Study as well as Pc, Volume 7, Issue No. 9, pp. 14838-- 14843

4. Ilona Buciuniene and also Vida Skudiene (2008), "Effect of Leadership Kind on Personnel Congregation' Organizational Devotion in Lithuanian Manufacturing Companies", The South East European Journal of Business economics as well as likewise Company, Vol 4, Concern 3, pp. 57-65. 